\title{
Wizyta profesora Tomasza F. Mroczkowskiego w Polsce
}

Gościem posiedzenia naukowo-szkoleniowego Oddziału Warszawskiego Polskiego Towarzystwa Dermatologicznego 21 czerwca 2018 r. był prof. Tomasz F. Mroczkowski, wykładowca na Wydziale Dermatologii Uniwersytetu Tulane'a, a także Sekcji Chorób Zakaźnych Uniwersytetu Stanowego Luizjany w Nowym Orleanie. Od początku swojej działalności naukowej prof. Mroczkowski zajmuje się problematyką chorób przenoszonych drogą płciową. W czasie wykładu, poza współczesnymi trendami epidemiologicznymi tych schorzeń, przedstawił ich niezwykle interesującą historię ukazaną przez pryzmat losów pisarzy, kompozytorów oraz innych wybitnych artystów, którzy mieli ogromne znaczenie dla ukształtowania światowej kultury.

dr n. med. Mariusz Sikora

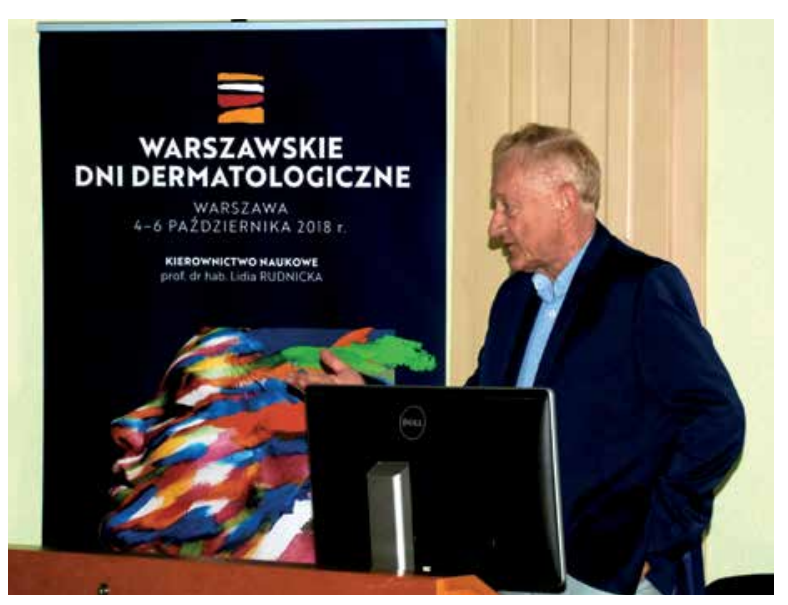

Profesor Tomasz F. Mroczkowski podczas wykładu na posiedzeniu Oddziału Warszawskiego PTD (fotografia: dr P. Gajda) 